\title{
Article
}

\section{Study On Harmful Effects Of Opium On Liver And Lungs In Chronic Opium Addicts Of Western Rajasthan}

\author{
Pawan $^{1}$, Raghuveer Choudhary ${ }^{2}$, Ranjana Mathur ${ }^{3}$, M.R. Choudhary ${ }^{4}$ Kamla $^{5}$
}

\begin{abstract}
Background: Today opium dependence is widely prevalent in certain states of India, especially Rajasthan, Punjab, Haryana, Madhya Pradesh (MP) etc. In rural areas of western Rajasthan crude opium is consumed with a social acceptance by a notable proportion $(8.0 \%)$ of adult male population. Later on they become addicted to it. Objective: to observe the changes in some liver and lung function parameters in opium addicted subjects of Barmer city of Western Rajasthan. Methods: The present study was conducted in district hospital of Barmer, Rajasthan. Total fifty (50) adult male subjects with age ranged from 30 to 50 years were participated in this study. Among them 25 were opium addicted and were considered as study group (Group B) and another 25 apparently healthy adult male of same age group were designated as control group (Group A). Opium addicts were consuming about 5-11 $\mathrm{gm} /$ day opium for $>2$ years. Then liver function tests were evaluated by estimating serum aspartate amino transferase (AST), alanine amino transferase (ALT), alkaline phosphatase and lung function tests by measuring $\mathrm{FVC}, \mathrm{FEV}_{1}, \mathrm{FEV}_{1} / \mathrm{FVC}$, $\mathrm{PEF}, \mathrm{FEF}_{25-75 \%}$ of both the groups. Results: In this study AST, ALT and alkaline phosphatase levels were found significantly $(\mathrm{p}<.05)$ higher in group B as compared to those of group A. Again, $\mathrm{FVC}, \mathrm{FEV}_{1}, \mathrm{FEV}_{1} / \mathrm{FVC}$ were significantly $(\mathrm{p}<.05)$ lower in group $\mathrm{B}$ as compared to those of group A. PEF ( $\mathrm{L} / \mathrm{sec})$ and $\mathrm{FEF}_{25-75 \%}$ were also significantly $(\mathrm{p}<0.001)$ lower in group B as compared to those of group A. Conclusion: it is concluded that chronic long term use of opium, increases the risk of hepatic and pulmonary damage.
\end{abstract}

Key words: Opium addiction, western Rajasthan, LFT, PFT

J Bangladesh Soc Physiol. 2011 December; 6(2): 122 - 126 For Authors Affiliation, see end of text.

http://www.banglajol.info/index.php/JBSP

\section{Introduction}

A

ddiction is an alarming issue in all over the world. In India, among the opioid compounds opium has the highest consumption; as India is one of the major opium producing \& exporting country. Botanically opium is known as Papaver somniferum which is available in chocolate colored gum form prepared by drying the poppy fruit milk on a cotton cloth in the hot sun.

Received July 2011; Accepted December 2011
The opium which is extracted from the juice of poppy capsules (Papaver-somniferum) ${ }^{1}$ is used as a raw material for the synthesis of some medicines such as morphine, noscapine and papaverine $(10 \%, 6 \%, 1 \% \text { of opium respectively })^{2}$. Since more than 20 alkaloid $^{3}$ and more than 70 ingredients are present in opium ${ }^{4}$, its impacts can be different in comparison to pure morphine, noscapine \& papaverin.

Since ancient times opium was used by Rajput (warrior) clan of this part of the country 
particularly in the desert part mainly to reduce bleeding and allay apprehension during war times. It was also used since long as a mind altering drug and as an analgesic on the IndoPakistan sub-continent ${ }^{5}$.

Furthermore, in India total number of registered addicts of opium were 1,10,866 in 2001. Opium dependence is gradually increasing in certain states of India, especially Rajasthan, Punjab, Haryana, M.P. etc. In rural areas of Western Rajasthan opium has also being used as ceremonial drink during the vital events, festivals and social functions ${ }^{6}$. Opium dependence is widely prevalent in rural areas of western Rajasthan where crude opium is consumed with a social acceptance by a notable proportion $(8.0 \%)$ of adult male population. Later on they become addicted to it ${ }^{7}$.

Barmer District has highest prevalence rate (8.4\%) of opium addiction. In addition, the number of opium addicted subjects is gradually increasing, but little is known about the harmful effect of opium. So, the present study was done to observe the changes in some liver and lung function parameters in opium addicted subjects of Barmer city of Western Rajasthan. The results of this study would help to create awareness among the clinician to give attention on liver and lung function abnormalities in opium addict's patients and in patients prescribed with different doses of opium.

\section{Methods}

The present study was conducted in district hospital of Barmer, Rajasthan. Total fifty (50) adult male subjects with age ranged from 30 to 50 years were participated in this study. Among them 25 were opium addicted and were considered as study group (Group B) and another 25 apparently healthy adult male of same age group were designated as control group (Group A). Opium addicts were consuming about 5-11 gm/day opium for $>2$ years. Then liver function tests were evaluated by estimating serum aspartate amino transferase (AST), alanine amino transferase (ALT), alkaline phosphatase and lung function tests by measuring $\mathrm{FVC}, \mathrm{FEV}_{1}, \mathrm{FEV}_{1} / \mathrm{FVC} \%$, $\mathrm{PEF}, \mathrm{FEF}_{25-75 \%}$ of both the groups.

The purpose and expected outcome of the study were explained to each subject. They were encouraged for voluntary participation. Written informed consent was obtained from each subject .Detailed medical and family history was taken and thorough clinical examination was done. Clinically known case of infections that affect liver \& lung like viral hepatitis, HIV, pneumonia,chronic obstructive lung disease, tuberculosis and subjects with history of smoking were excluded from the study.

After an overnight fast $(5 \mathrm{ml})$, blood samples were taken. Blood sugar level ${ }^{8} \mathrm{AST}^{9}, \mathrm{ALT}^{9}$, total bilirubin ${ }^{10}$, Alkaline phosphatase ${ }^{11}$ were estimated in both the groups. Various pulmonary parameters were measured using vitalograph.

Statistical analysis was done by Student's " $\mathrm{t}$ "test

\section{Results}

Subjects of both the groups were matched for age, height and weight. (Table I)

Table I : Mean \pm SD Anthropometric parameters of both the groups $(n=50)$.

\begin{tabular}{lccc}
\hline Parameter & $\begin{array}{c}\text { Group A } \\
(\mathrm{n}=25)\end{array}$ & $\begin{array}{c}\text { Group B } \\
(\mathrm{n}=25)\end{array}$ & $\begin{array}{c}\mathrm{P} \\
\text { value }\end{array}$ \\
\hline Age (years) & $39.5 \pm 9.20$ & $39.2 \pm 11.14$ & $>.05$ \\
Height & $165 \pm 7.60$ & $163 \pm 8.9$ & $>.05$ \\
Weight & $57 \pm 6.39$ & $53 \pm 5.86$ & $>.05$ \\
\hline
\end{tabular}

Group A = apparently healthy subjects Group B= Opium addicts

J Bangladesh Soc Physiol. 2011 December; 6(2) : 122-126 
Table II: Mean \pm SD some liver function tests in both the groups $(\mathrm{n}=50)$

\begin{tabular}{lccc}
\hline Parameter & $\begin{array}{c}\text { GroupA } \\
(\mathrm{n}=25)\end{array}$ & $\begin{array}{c}\text { G+roup B } \\
(\mathrm{n}=25)\end{array}$ & $\begin{array}{c}\text { P } \\
\text { value }\end{array}$ \\
\hline BloodSugar(mg/dl) & $78.5 \pm 42.46$ & $104.9 \pm 61.18$ & $>.05$ \\
S. Bilirubin (mg/dl) & $0.54 \pm 0.32$ & $0.97 \pm 0.61$ & $>.05$ \\
SGOT(IU/L) & $27.5 \pm 6.94$ & $47.2 \pm 16.54$ & $<.05$ \\
SGPT(IU/L) & $26.0 \pm 6.26$ & $80.7 \pm 21.96$ & $<.001$ \\
ALP(IU/L) & $158.12 \pm 52.31$ & $228.0 \pm 60.41$ & $<.05$ \\
\hline
\end{tabular}

Table III: Mean \pm SD some pulmonary function tests in both the groups $(\mathrm{n}=50)$

\begin{tabular}{lccc}
\hline Parameters & $\begin{array}{c}\text { GroupA } \\
(\mathrm{n}=25)\end{array}$ & $\begin{array}{c}\text { Group B } \\
(\mathrm{n}=25)\end{array}$ & $\begin{array}{c}\text { P } \\
\text { value }\end{array}$ \\
\hline FVC(L) & $4.20 \pm 1.34$ & $3.29 \pm 1.62$ & $>.059$ \\
$\mathrm{FEV}_{1}(\mathrm{~L})$ & $4.20 \pm 1.41$ & $2.00 \pm 1.50$ & $<.001$ \\
$\mathrm{FEV}_{1} / \mathrm{FVC}$ & $92.0 \pm 8.93$ & $71.78 \pm 12.96$ & $<.001$ \\
$\mathrm{PEF}(\mathrm{L} / \mathrm{Sec})$ & $5.80 \pm 1.38$ & $3.20 \pm 0.82$ & $<.001$ \\
$\mathrm{FEF}(25-75 \%)(\mathrm{L} / \mathrm{Sec})$ & $5.40 \pm 1.68$ & $2.95 \pm 1.51$ & $<.001$ \\
\hline
\end{tabular}

Group A = apparently healthy subjects. Group B= Opium addicts

Blood sugar and serum bilirubin levels were higher in group B in comparison to those of group A but the differences were not statistically significant $(\mathrm{p}$ $>0.05$ ). AST, ALT and alkaline phosphatase levels were significantly $(\mathrm{p}<.05)$ higher in group $\mathrm{B}$ than those of group A. (Table II)

In this study, FVC, FEV1, FEV1/ FVC\% were significantly $(\mathrm{p}<.05)$ lower in group B than those of group A. Again, PEF and FEF were also significantly $(\mathrm{p}<.001)$ lower in group $B$ as compared to those of group A. (Table III)

\section{Discussion}

In the present study AST, ALT and alkaline phosphatase levels were significantly higher in opium addict group than those of control group.
Similar results were observed by other researchers ${ }^{15-17}$.

In liver, morphine is biotransformed by hepatic glucoronidation to major but inactive metabolite morphine- 3 glucuronide (M3G) and biologically active morphine- 6 glucuronide $(\mathrm{M} 6 \mathrm{G})^{12}$. These metabolites increase the secretion of enzymes in liver. Continuous and larger dose of opium can impaired the liver functions. Morphin is metabolized mostly in the liver with prolonged clearance because of enterohepatic circulation which contributes to the maintenance of blood and tissue level of morphine and its metabolites from intestinal hydrolysis of glucuronides ${ }^{13}$.

Furthermore, in this study FEV1, FEV1/FVC, PEF $\& \mathrm{FEF}_{25-75 \%}$ were significantly lower in opium 
addict group as compared to those of control group. The FVC was also reduced in opium addict group but it was not statistically significant. These results are in consistent with those of some other researchers ${ }^{19-24}$.

Morphine directly acts on the respiratory center and decreases respiratory function 18 . Therapeutic doses of morphine in man depress all the phases of respiratory activity in terms of rate, minute volume and tidal volume. Besides centrally mediated respiratory depression overdose of opioids may affect the respiratory system directly by causing non-cardiogenic pulmonary oedema and bronchospasm. ${ }^{12}$ Opium also affects parenchyma, pleura or mediastinum. Very high doses of opioids may induce centrally mediated muscle rigidity of chest and abdominal wall.

\section{Conclusion}

From this study it is concluded that chronic long term use of opium, $(>2 \mathrm{yr})$ increases the risk of hepatic \& pulmonary damage.

\section{Authors Affiliation}

1. Post graguate (Msc Bio-Chemistry) Dr S.N.Medical College ,Jodhpur

*2. Associate Professor Dept. of Physiology Dr S.N.Medical College, Jodhpur, 4F/54 New Power House Road, Jodhpur 342001, Rajasthan India Email- drraghu74@yahoo.com Cell-91-09 829216643

3. Professor Dept. of Biochemistry Dr S.N.Medical College ,Jodhpur

4. Tutor Dept. of Biochemistry Dr S.N.Medical College ,Jodhpur

5. Tutor Dept. of Physiology Dr S.N.Medical College, Jodhpur

\section{* For corrospondance}

\section{References}

1. Kalant H. Opium revisited: a brief review of its nature, composition, non-medical use and relative risks. Addiction 1997; 92(3): 267-77.

2. Hanson G. Analgesic, antipyretic and antiinflammatory drugs. In: Gennard AR, Editor. The science and practice of pharmacy. 19th ed. New
York: Mack Publishing Company; 1995. p. 11978.

3. Venturella VS. Natural Product. In: Gennard AR, Editor. The Science and Practice of Pharmacy. 19th ed. New York: Mack Publishing Company; 1995. p. 400-2.

4. Buchbauer G, Nikiforov A, Remberg B.Headspace. Constituents of opium. Planta Med 1994; 60(2) :181-3.

5. Dwarakanath C. Use of opium and cannabis in the traditional system of medicine in India. Bull Narct 1965; 27: 13-19.

6. Purohit DR. Community approach to opium dependent subjects in rural areas of Rajasthan. J Comm Psy 1988; 11(2): 3.

7. Mathur ML, Bansal RK. Prevalence of opium consumption in rural population of a desert district, Jodhpur. Indian J Public Health 1991; 35(4): 117-8.

8. Bergmeyer HV. Method of Enzymatic Analysis $1974 ; 1196: 42-46$.

9. Bergmeyer HU, Horder M. Approved recommendation (1985) on IFCC Method for the measurement of catalytic concentration of enzymes. J Clin Biochem1986; 24 :497- 510.

10. Jendrassik, L.\& Grop.P. Biochem Z 1938; $297,81$.

11. Henery RJ. Enzymes in Clinical chemistry principal and techniques. 2nd ed. New York :Harper \& row publisher ; 1974. 815 p.

12. Richard KR, Shannon C, Miller,DA, Fiellin RSZ. Princiles of Addiction Medicine $.4^{\text {th }}$ ed. Lippincott: Williams and Wikins; p 126-130.

13. Hank GW and Aherne GW. Morphine metabolism: Lancet 1985;1 : 221 .

14. Aticis, Clinel I, Dark N, Eskandari G . Liver and kidney toxicity in chronic uses of opioids. J Biosci $2005 ; 30(2): 245-252$.

15. Wynne AG, M-6-G, An important factor in interpreting morphine radioimmunoassays. Lancet 1983; July 27 (I): 210-11.

16. Bergelleca. Toxicology evaluation of $\mu$-agonist with levo-alpha acetyl methadol- hydrochloride (AMM) and morphine. J Appl L Toxicol 1994; 14: 435445 .

17. Nagmastsu K, Takahashi A . Morphine metabolism in isolated rat hepatocytes. Biochem. Pharmacol $1988 ; 3543-3548$. 


\section{Article}

18. Bates. A comparision of the respiratory of depressant effects of dextropropoxene and morphine in man. J Pharmacol Exp Ther 1968; 9 : 438-434.

19. Davis TM. Adeverse effect of opioid on liver and lungs. Br J Patho 1999; 59: 61-67.

20. Bates. Benefits assessment of opioids. Drug Saf 2000; 21: 283-296.

21. Enright PL. Respiratory sensitivity of the infants and addicts to meperdine and morphine. Clin Pharmocol Ther 2000; 454-461.
Effect of opium on liver and lung in opium addicts

22. MCOSA. Comparative analysis of the effect of alcoholism and opium addicts on liver function. Fiziol Zh 2004; 47 (2): 81-6.

23. Govaresh. Influence of pulmonary failure on the disposition of morphine, M -3-G and M-6-G. Am J Med 2007;120:145-190.

24. Phatak MS : Lipid peroxidation, peroxyl radicalscavenging system of palasma and liver patrhalogy in adolescence hertoin and morphine users. Voper. Med. Khim,2008 45; 501-50-6. 